\title{
PERTANGGUNGJAWABAN PIDANA TERHADAP PELAKU TINDAK PIDANA PENYELUNDUPAN MANUSIA (PEOPLE SMUGGLING)
}

\author{
Oleh: \\ I Dewa Agung Gede Mahardhika Martha ${ }^{1}$
}

\begin{abstract}
People smuggling is an example of organized transnational crimes which happen in many countries around the world including Indonesia which has been used as a transit country by human smugglers. To overcome this problem, Indonesia formulated a law called Undang-Undang No. 6 Tahun 2011 about immigration. The method used for this research is normative legal theory, due to the void norm related liability criminal offense of people smuggling conducted by the organization. The purpose of this research is to find factors which make Indonesia as a transit country as well as to find criminal liability for smugglers based on Indonesian positiflaw. Revealing the difficulty in monitoring big total Indonesian territory, strategic position of Indonesia, national law instruments which is way too weak, and the presence of people holding the authority helping the smugglers leading Indonesia to become a favorite transit country. In addition to that, the law enforced penalties for the smugglers which are relatively light comparing to the criminal responsibility for drug smuggling and human trafficking make this crime grows as a promising business in Indonesia.
\end{abstract}

Keywords: criminal responsibility criminal offense, people smuggling.

\begin{abstract}
Abstrak
Penyelundupan manusia merupakan salah satu bentuk kejahatan transnasional terorganisasi yang menimbulkan permasalahan di berbagai belahan dunia, termasuk Indonesia yang dimanfaatkan sebagai negara transit oleh pelaku penyelundupan manusia. Untuk menanggulangi kejahatan ini, Indonesia membentuk Undang-Undang No. 6 Tahun 2011 tentang Keimigrasian. Metode penelitian hukum yang digunakan dalam tulisan ini adalah metode penelitian hukum normatif, sebab terdapat kekosongan norma terkait dengan pengaturan pertanggungjawaban pidana yang dilakukan oleh organisasi. Tujuan dari tulisan ini adalah untuk mengetahui faktor-faktor yang menjadikan Indonesia sebagai negara tujuan transit serta mengetahui pertanggungjawaban pidana pelaku penyelundupan manusia menurut hukum positif Indonesia. Sulitnya pengawasan terhadap wilayah kepulauan Indonesia yang sangat luas, letak Indonesia yang sangat strategis, lemahnya instrumen hukum nasional yang ada serta adanya oknum pejabat yang berperan dalam kegiatan ini menempatkan Indonesia sebagai negara favorit untuk transit. Di samping itu, pertanggungjawaban pidana terhadap pelaku yang relatif ringan sebagaimana diatur dalam UndangUndang Keimigrasian juga mengakibatkan kejahatan ini berkembang menjadi bisnis yang menguntungkan di Indonesia.
\end{abstract}

Kata Kunci: pertanggungjawaban pidana, tindak pidana, penyelundupan manusia.

Mahasiswa Magister Ilmu Hukum Universitas Udayana, Denpasar, Bali. Alamat Jalan Drupadi XVII/ No 11 Denpasar, email dewadhika_boxer@yahoo.com / fozzielboxer.gbyolality@gmail.com 


\section{PENDAHULUAN}

\subsection{Latar Belakang}

Perkembangan teknologi dan informasi di bidang transformasi, baik darat, laut maupun udara yang dewasa ini mengalami kemajuan dengan pesat, sehingga memberikan kemudahan bagi penggunanya untuk mengakses tempat yang diinginkan. Pesatnya perkembangan tersebut, berbanding lurus dengan kejahatan lintas negara (transnational crime) yang belakangan ini makin marak terjadi, terutama di wilayah perairan Indonesia yang sering kali disebut sebagai daerah transit bagi para imigran gelap atau illegal. ${ }^{2}$

Salah satu kejahatan lintas batas Negara yang sering kali memanfaatkan wilayah Indonesia sebagai tempat transit adalah penyelundupan manusia atau yang popular dengan istilah people smuggling. Penyelundupan manusia diklasifikasikan sebagai kejahatan transnasional terorganisasi dengan wilayah operasi yang luas. Indonesia adalah salah satu wilayah negara yang dijadikan target untuk tempat transit para imigran illegal sebelum diselundupkan ke tempat tujuan, yaitu negara-negara di Benua Australia. Fenomena inilah yang menjadikan penyelundupan manusia sebagai tindak pidana yang sangat serius ditangani oleh seluruh lapisan masyarakat dunia. Oleh karena itu, sangat penting bagi

2 Ady, 2013, "Tidak mudah Tangani Imigran Gelap, Butuh Regulasi yang Kuat dan Anggaran yang Cukup", Hukum Online, URL: http://m.hukumonline.com/berita/baca/ tidak-mudah-tangani-imigran-gelap. diakses tanggal 26 Februari 2016.
Indonesia memiliki pengaturan yang tegas mengatur hal-hal yang berkaitan dengan penyelundupan manusia ini. Sebagai Negara kepulauan dengan kondisi geografis wilayah perairan yang luas, Indonesia menempati posisi yang rentan terhadap berbagai bentuk penyelundupan, termasuk salah satunya penyelundupan manusia tersebut. Pada perkembangannya masalah penyelundupan manusia menjadi semakin kompleks, yang awalnya sekedar mencari tempat penghidupan yang layak, lambat laun berkembang menjadi sebuah kegiatan terorganisir yang berorientasi pada "profit" semata. ${ }^{3}$ Dalam melakukan aksinya sindikat penyelundupan manusia melibatkan banyak orang dengan peran berbeda yang dapat dibagi menjadi tiga tingkatan. Bahkan dalam beberapa kasus tindak pidana penyelundupan manusia, ada diantara mereka yang memiliki peran ganda, yaitu sebagai orang yang diselundupkan dan sekaligus berperan sebagai penyelundup (smuggler). Untuk dipahami bahwa masingmasing peran yang dilakukan oleh pelaku menimbulkan kesalahan yang berbeda. Yang kemudian digunakan sebagai acuan dalam menentukan pertanggungjawaban pidana pelaku tindak pidana penyelundupan manusia.

\footnotetext{
International Organisasi for Migration, 2012, Petunuk Penanganan Tindak Pidana Penyelundupan Manusia: Pencegatan, Penyidikan, Penuntutan dan Koordinasi di Indonesia, International Organization for Migration, Jakarta, hlm. 19.
} 
Ketentuan

Undang-Undang No. 6 Tahun 2011 tentang Keimigrasian belum mampu memberikan sebuah pemahaman terkait dengan apa dan bagaimana yang dimaksud kejahatan terorganisasi sehingga berdampak pada pertanggungjawaban pidana yang tidak tepat sasaran. Pemahaman ini sangat penting ditanamkan terutama terhadap para legislator, agar peraturan perundang-undangan yang dibentuk dapat mewujudkan peraturan yang proporsional terkait dengan pertanggungjawaban pidana terhadap pelaku tindak pidana penyelundupan manusia ke dalam bentuk hukum nasional. begitu pula untuk para penegak hukum, akan memiliki dasar yang kuat untuk menjerat pelakupelaku yang terlibat.

\subsection{Perumusan Masalah}

Berdasarkan dari latar belakang diatas, yang menjadi rumusan masalah adalah sebagai berikut ;

1. Apa yang menyebabkan Indonesia dijadikan sebagai negara tujuan transit untuk penyelundupan manusia?

2. Bagaimana pertanggungjawaban pidana pelaku tindak pidana penyelundupan manusia menurut hukum positif Indonesia?

\subsection{Tujuan Penulisan}

Tujuan dari penulisan ini adalah untuk memahami faktor yang menyebabkan Indonesia dijadikan sebagai negara tujuan transit untuk penyelundupan manusia dan untuk memahami pertanggungjawaban pidana pelaku tindak pidana penyelundupan manusia menurut hukum positif Indonesia.

\section{METODE PENELITIAN}

Metode yang digunakan dalam karyailmiahiniadalahmetodepenelitian hukum normatif, karena adanya kekosongan norma terkait dengan pengaturan pertanggungjawaban pidana yang dilakukan oleh organisasi. Jenis pendekatan yang digunakan adalah pendekatan perundangundangan (statute approach) yaitu dengan mengkaji peraturan perundang-undangan terkait dengan penyelundupan manusia.

III. HASIL DAN PEMBAHASAN 3.1 Negara Indonesia Sebagai Negara Tujuan Transit Untuk Penyelundupan Manusia

Sebagai jalur pelayaran internasional, ancaman terhadap kedaulatan dan wilayah Indonesia berada di wilayah perairan. Hal ini semakin serius manakala Indonesia berada dalam jalur lalu lintas perdagangan dunia, karena posisinya yang sangat strategis. Dengan letak demikian strategis, praktis menjadikan Indonesia sebagai jalur yang padat akan lalu lintas Internasional, baik melalui jalur darat, laut maupun udara. Jalur ini merupakan jalur penghubung berbagai macam kegiatan ekonomi, social dan budaya 
olehNegara-negaradidunia,khususnya di kawasan Asia dan Australia. Tentu saja hal ini sangat menjanjikan potensi perekonomian yang baik bagi Negara berkembang seperti Indonesia. Selain itu dari segi sosial dan budaya, dengan banyaknya interaksi dengan dunia luar menjadikan Indonesia lebih dikenal dalam pergaulan Internasional serta tidak menutup kemungkinan terjadinya akulturasi antara budaya Indonesia serta Negara-negara sekitar yang dapat menambah ragam budaya yang ada. Akan tetapi di balik potensi yang ada dan menjanjikan keuntungan dari sisi ekonomi, sosial bahkan budaya. Letak yang strategis ini juga menjadi momok bagi Indonesia. Kondisi ini menghadapkan Indonesia pada kenyataan bahwa wilayahnya sering kali dijadikanjaluryang digunakan oleh para sindikat kejahatan Internasional untuk melakukan aksinya. Sebut saja penyelundupan manusia, salah satu kejahatan lintas batas Negara yang belakangan sering terjadi di wilayah Indonesia, terutama wilayah perairan yang digunakan sebagai pintu untuk keluar dan masuk. Keamanan daerah perairan dan keselamatan pelayaran menjadi hal yang penting untuk mendukung kelancaran perdagangan dunia. Akan tetapi kejahatan lintas batas Negara bukanlah hal yang mudah untuk dihadapi, salah satu yang sangat serius dan sedang dihadapi Indonesia saatiniadalahkejahatanpenyelundupan manusia. Tragedi kemanusiaan yang tak kunjung usai mengakibatkan terjadinya eksodus penduduk yang sulit untuk dibendung. Kekuatiran akan rasa aman atas keselamatan diri karena tertekan, baik karena faktor politik maupun konflik yang berkepanjangan menjadikan banyak warga berusaha mencari tempat yang aman dan berharap dapat memperbaiki kehidupannya. Salah satu cara yang ditempuh adalah menyelundupkan diri ke negara-negara yang dituju dengan melalui wilayah perairan Indonesia. Di samping itu, terungkapnya fakta bahwa dalam beberapa kasus penyelundupan manusia yang terjadi, melibatkan oknum pejabat terkait sehingga mempermudah pergerakan jaringan penyelundupan manusia di Indonesia. Sebagaimana diberitakan oleh media online TEMPO.COM bahwa "Lima oknum TNI AD yang terlibat penyelundupan imigran menerima imbalan ratusan juta rupiah atas peran yang mereka jalankan. ${ }^{4} \mathrm{Hal}$ tersebut sudah dimulai sejak tahun 2010 dan telah terlibat beberapa kali dalam penyelundupan ratusan imigran asal Timur Tengah ke Australia.

Kegiatan penyelundupan manusia ini dapat dipastikan melibatkan beberapa negara yang dibedakan berdasarkan negara asal (countries or origin), negara transit (countries of transit) dan negara

Ishomuddin, 2012, "Selundupkan Imigran, Oknum TNI Dapat Ratusan Juta", TEMPO. CO, URL:m.tempo.co/read/news/2012/09/1 2/063428916/Selundupkan-Imigran-OknumTNI-Dapat-Ratusan-Juta. diakses 21 Januari 2016. 
tujuan (countries of destination). Berdasarkan tiga pembagian tersebut, Indonesia termasuk ke dalam negara yang digunakan sebagai tempat transit atau countries of transit oleh para imigran illegal.

Adapun faktor-faktor yang menyebabkanIndonesiamenjadinegara transit bagi kegiatan tindak pidana penyelundupan manusia diantaranya wilayah Indonesia yang memiliki kondisi geografis berupa perairan luas dengan pulau yang berjumlah ribuan seringkali mempersulit para petugas dalam melakukan pengawasan terhadap lokasi yang rawat terjadinya penyelundupan manusia, ${ }^{5}$ terlebih lagi dengan sarana dan prasarana yang kurang memadai untuk daerahdaerah perbatasan terutama armada laut yang tidak memadai untuk memagari wilayah perairan Indonesia, letak yang sangat strategis di antara negara asal para imigran illegal yang sebagian besar berasal dari Timur Tengah dan negara tujuan penyelundupan, lebih tepatnya bersebelahan dengan negara tujuan (countries of destination), yaitu negara-negara di Benua Australia. Belum lagi hukum nasional yang lemah serta masyarakat dan oknum pejabat yang mudah diajak kerja sama untuk menyelundupkan imigran illegal ke negara tujuan, menjadikan Indonesia sebagai tempat yang sangat potensial untuk melakukan transit.

International Organization for Migration, op.cit, hlm. 18.

\subsection{Pertanggungjawaban Pidana Pelaku Tindak Pidana Penyelundupan Manusia Menurut Hukum Positif Indonesia}

Jauh sebelum berlakunya Undang-undang No. 6 Tahun 2011 tentang Keimigrasian, telah ada Undang-undang Darurat No.8 Tahun 1955 tentang Pidana Imigrasi dan Undang-undang No.9 Tahun 1992 tentang Keimigrasian, namun hanya mengatur tentang orang asing yang masuk dan keluar Indonesia dengan pemalsuan dokumen atau tidak resmi dan menyalahi aturan yang ada disertai dengan sanksi penjara dan denda, akan tetapi belum dikenal istilah penyelundupan manusia atau yang popular dengan sebutan people smuggling di dunia Internasional.

Undang-undang No. 6 Tahun 2011 tentang Keimigrasian tidak memberikan definisi terkait apa yang dimaksud dengan unsur "setiap orang". Bila dicermati semua pasal, dapat disimpulkan bahwa unsur"setiap orang tersebutmengandungpengertianbahwa yang dapat dipidana jika melakukan tindak pidana penyelundupan manusia, tidak seseorang atau kelompok orang (Pasal 120 ayat (1)), akan tetapi dapat juga dilakukan oleh korporasi(Pasal 136 ayat (1)). Terkait dengan pertanggungjawaban pidananya berdasarkan kesalahan (Liability based on fault). Undang-undang ini tidak menjelaskan tentang apa dan bagaimana kejahatan yang dilakukan oleh pelaku yang terorganisasi serta 
tidak diaturnya delik berkualifikasi bagi pelaku. Sebagai kejahatan yang jaringannya tersebar di berbagai belahan dunia, banyak orang dilibatkan dalam melakukan tindak pidana penyelundupan manusia.

Begitu lemahnya Undangundang ini sehingga yang dapat dijerat hanyalah pelaku-pelaku dengan peran yang kecil yang sesungguhnya hanya dimanfaatkan oleh jaringan yang akan menyelundupkan para imigran illegal melalui Indonesia, seperti nelayan yang menyewakan kapal atau perahunya, Anak Buah Kapal (ABK) yang membantu untuk menyeberang, sopir yang mengantarkan mereka ke tempat tujuan ataupun yang memberikan penginapan untuk para imigran illegal tersebut.

Penyelundupan manusia merupakan transnasional organized crime yang melibatkan banyak orang denganberbagaiperandengantingkatan tertentu. Pada tingkat paling bawah (pertama) adalah pelaksana lapangan, tingkat kedua adalah koordinator yang mengkoordinir kegiatan pelaksanaan lapangan dan tingkat ketiga adalah pengendali yang mengendalikan kegiatan para koordinator. ${ }^{6}$ Beberapa kasus penyelundupan manusia menunjukan tidak semua orang yang akan diselundupkan merupakan imigran illegal murni. Ada diantara mereka yang memiliki peran ganda, yaitu sebagai orangyang diselundupkan dan sekaligus berperan sebagai

Ibid, hlm. 107. penyelundup (smuggler). Untuk itu harus dibedakan peran masing-masing pelaku, agar dapat melihat kesalahan apa yang dilakukan pelaku dan dapat menentukan pertanggungjawaban atas kesalahan yang dilakukan. Ironisnya, belakangan diketahui dalam beberapa kasus penyelundupan manusia bahwa banyak dari mereka yang terlibat merupakan oknum-oknum pejabat. Mereka yang menyalahgunakan kekuasaan dan kewenangan yang dimiliki untuk membantu kegiatan para sindikat penyelundupan manusia. Lebih dari pada itu, "people smuggling is a crime that is directly or indirectly linked to other transnasional crime, such as drug trafficking, trafficking in persons (human trafficking) and terrorism. ${ }^{7}$ Maka tidak berlebihan apabila dianggap sebagai kejahatan yang merupakan musuh umat manusia (hostis humani generis). ${ }^{8}$

Berdasarkan hukum positif Indonesia, pertanggungjawaban pidana pelaku tindak pidana penyelundupan manusia didasarkan pada ketentuan Undang-Undang No. 6 Tahun 2011 tentang Keimigrasian. Hal ini diatur dalam Pasal 120 ayat (1) dimana terhadap setiap orang yang melakukan penyelundupan manusia dipidana penjarapalingsingkat 5 tahundanpaling

\footnotetext{
International Organization for Migration, 2012, Operational Booklet for the Coordinated Handling of People Smuggling, International Organization for Migration, Jakarta, hlm. 73. I Wayan Parthiana, 2003, Hukum Pidana Internasional dan Ekstradisi, Cet. Kesatu, Yrama Widya, Bandung, hlm. 41.
} 
lama 15 tahun dan denda paling sedikit Rp 500.000.000, dan paling banyak Rp 1.500.000.000,- Pidana yang sama juga dikenakan terhadap percobaan untuk melakukan tindak pidana ini dan diatur dalam Pasal 120 ayat (2). Terhadap mereka yang melakukan tindak pidana penyelundupan manusia dengan menyalahgunakan jabatan dan wewenang hanya dikenakan ancaman pidana pokok, yaitu lima tahun penjara. Sedangkan untuk tindak pidana penyelundupan manusia yang dilakukan oleh korporasi hanya dipidana dengan ketentuan besarnya pidana 3 (tiga) kali lipat (Pasal 136 ayat (2)). Sedangkan peran dan kualifikasi tindak pidana belum diatur di dalam Undang-undang ini, sehingga yang dapat dijerat dalam pelaksanaannya pelaku yang kecil muncul ke permukaan, akan tetapi pelaku utamanya masih bebas berkeliaran menikmati keuntungan dan udara segar.

\section{PENUTUP}

\subsection{Simpulan}

1. Faktor-faktor yang menyebabkan Indonesia dipilih sebagai negara transit untuk kegiatan penyelundupan manusia diantaranya sulitnya pengawasan terhadap wilayah kepulauan Indonesia, sarana dan prasarana untuk pengawasan yang kurang memadai, letak Indonesia yang berada di antara negara asal dan negara tujuan penyelundupan manusia dan keterlibatan masyarakat serta oknum pejabat terkait yang membantu menyelundupkan para imigran.

2. Undang-Undang Nomor 6 Tahun 2011 tentang Keimigrasian tidak membedakan derajat kesalahan pelaku berdasarkan perannya. Dengan kata lain, selama unsur-unsur pasal tindak pidana penyelundupan manusia terpenuhi, apapun perannya, pelaku akan diancam dengan hukuman pidana sesuai dengan ketentuan pidana pada pasal yang dilanggar.

\subsection{Saran}

1. Perlu adanya koordinasi antara pihak dari imigrasi dengan aparat keamanan di kepolisian dan TNI AL agar dapat lebih melakukan ketat mengawasi terhadap pintu masuk - pintu masuk yang berpotensi menjadi tempat masuknya para pelaku tindak kejahatan penyelundupan manusia sehingga negara Indonesia tidak lagi dijadikan sebagai Negara transit penyelundup perdagangan manusia

2. Perlu adanya revisi terhadap pasal-pasal dalam undangundang keimigrasian sehingga tidak adanya ketimpangan pemberian sanksi pidana bagi pelaku tindak pidana perdagangan manusia 


\section{DAFTAR PUSTAKA}

\section{Buku}

International Organisasi for Migration, 2012, Petunuk Penanganan Tindak Pidana Penyelundupan Manusia: Pencegatan,

Penyidikan, Penuntutan dan Koordinasi di Indonesia, International Organi-zation for Migration, Jakarta.

International Organization for Migration, 2012, Operational Booklet for the Coordinated Handling of People Smuggling, International Organization for Migration, Jakarta.

I Wayan Parthiana, 2003, Hukum Pidana Internasional dan Ekstradisi, Cet. Kesatu, Yrama Widya, Bandung.

\section{Internet}

Ady, 2013, "tidak Mudah Tangani Imigran Gelap, Butuh Regulasi yang Kuat dan Anggaran yang Cukup", Hukum Online, URL: htt://m.hukumonline.com/berita/ baca/tidak-mudah-tanganiimigran-gelap. Diakses tanggal 26 Februari 2016.

Ishomuddin, 2012,"Selundupkan Imigran, Oknum TNI Dapat Ratusan Juta",TEMPO.COURL: $\mathrm{m}$. tempo.co/read/news $/ 2012 / 0$ 9/12/036428916/SelundupkanImigran-Oknum-TNI-DapatRatusan-Juta. Diakses tanggal 21 Februari 2016

\section{Peraturan Perundang-Undangan} Undang-Undang No. 6 Tahun 2011 tentang Keimigrasian, Lembaran Negara Nomor 52 Tahun 2011, Tambahan Lembaran Negara No. 5216. 